\title{
At the crossroads: Geography, gender and occupational sector in employment-related geographical mobility
}

\author{
Michael $\operatorname{Haan}^{* 1}$ \\ Deatra Walsh* \\ Barbara Neis
}

\begin{abstract}
In Canada, patterns of employment-related geographical mobility (E-RGM) are becoming more complex and nuanced, with implications for employers, workers, and their families. This article introduces the concept of E-RGM, and argues that because mobility is a pervasive aspect of working lives in Canada, it deserves more systematic and extensive research. To date, most studies of labour mobility have focused on permanent relocation or short-distance daily commuting. We argue for more research that disaggregates the socio-economic characteristics of those engaged in E-RGM and untangles its complexity. Using the 2006 Canadian confidential master file to create a statistical portrait of E-RGM reveals considerable variation among the Canadian working population, particularly those engaging in more extensive work journeys.
\end{abstract}

Keywords: Canadian census, employment, mobility, commuting.

\section{Résumé}

Au Canada, les tendances de mobilité géographique reliée à l'emploi (MGRE) sont de plus en plus complexes et nuancées avec des implications au tant pour les employeurs que pour les travailleurs et leur famille. Cet article introduit le concept de MGRE et soutient que la mobilité est un aspect omniprésent de la vie des travailleurs au Canada qui mérite d'être étudiée de façon systématique et avec des recherches approfondies. Jusqu'à maintenant, la plupart des études portant sur la mobilité de la main-d'œuvre se sont concentrées sur les relocations permanentes ou les déplacements quotidiens à courte distance. Nous soutenons que plus de recherches sur les caractéristiques socioéconomiques de ceux qui participent à la MGRE sont requises afin de mieux comprendre le phénomène. En utilisant le fichier maitre confidentiel du recensement canadien de 2006 pour créer un portrait statistique de la MGRE, nous observons une variation considérable parmi la population active canadienne, en particulier chez ceux qui voyagent de longues distances pour le travail.

Mots-clés : recensement Canadien, emploi, mobilité, déplacement.

\section{Introduction}

Growing numbers of employees are commuting for work on a regular basis within or between countries, provinces, counties, and municipalities (Dobson and Sennikova 2007; Green 2004;

1. 'Co-lead authors. Corresponding author: Michael Haan, Department of Sociology, University of New Brunswick, Fredericton NB. E-mail: mhaan@unb.ca. 
Haan et al.: Geography, gender, and occupational sector in employment-related geographical mobility

Helminen and Ristimaki 2007; Penninx et al. 2008; Sandow 2008). In Canada, as elsewhere, journeys to and from work are becoming more sustained and complex in terms of time consumed, distance travelled, stops along the way, and time spent away from home (Clark 2000; Statistics Canada 2008a; Heisz and Larochelle-Cote 2005a, 2005b; Stabler and Rounds 1997; Turcotte 2005). Intra- and interurban daily commuting is widespread, as is rural-urban and urban-rural commuting (Ali et al. 2011; Green and Meyer 1997; Harris et al. 2008; Mitchell 2007; Shearmur and Motte 2009; Shearmur and Polese 2007). Inter-provincial travel for work is also common; it can last for months and can include entire families (HRLE 2011; Marshall 2009; MacDonald et al. 2012; Walsh 2012). In addition, an unknown number of Canadians work outside the country for varying lengths of time (Statistics Canada 2008), and many skilled and unskilled temporary foreign workers (TFWs) are employed in Canada through a growing array of provincial and federal programs (Fudge and MacPhail 2009; Thomas 2009).

In this paper, we contextualize some of these changing journey-to-work patterns in terms of wider societal shifts that have facilitated and, in some cases, necessitated increased mobility among the labour force. These include: changes in the nature of employment; a relative decline in transportation costs; shifts taking place in the Canadian economy nationally, regionally, and even locally; and the erosion of public policies, which once favoured labour immobility but now increasingly favour labour mobility.

We use the 2006 Canadian census confidential master file to create a statistical portrait of what we refer to as employment-related geographical mobility (E-RGM). The spectrum of E-RGM ranges from those who work at home (or in their home community and thus engage in little or no mobility) to those whose journeys to and from work span larger distances-including across provincial, and sometimes national, boundaries. Although previous Canadian commuting studies provide important insights about certain aspects of E-RGM, none look at the whole spectrum, as we do here. This research offers key insights into whether and how women are distributed differently across the spectrum; whether certain industries are associated with higher proportions of E-RGM categories; and how income, education, household composition, and E-RGM are interrelated. We argue that a statistical portrait is the means through which larger questions can be asked about the opportunities and challenges associated with commuting to work for workers, employers, and the communities.

This article begins with a discussion of the context for the current research and the appropriateness of Census data for undertaking an E-RGM analysis. We describe the approach used to create five E-RGM spectrum categories, and we present descriptive analyses of those engaged in E-RGM. We then use an ordered logit regression model to identify the correlates of E-RGM in a multivariate framework. We conclude by discussing our findings in light of changing trends in the Canadian labour market, including labour market insecurity, and a focus on their gendered occupational dimensions.

\section{Research context}

Studies indicate that distances travelled to work, and the time spent in transit, are increasing globally (Helminen and Ristimaki 2007; Sandow 2009). This growth in E-RGM can be attributed to several related trends. Industrial restructuring, rationalization, and labour-shedding practices among firms have meant that workers are increasingly expected to be mobile (Bauman 2000). Labour market insecurity, brought on by local, national, and global economic volatility, has increased the necessity for some workers to travel farther distances to find employment. In locations where mismatches between labour supply and demand exist, labour shortages have led to the recruitment of workers from other regions and countries (Hiller 2009). Mobile jobs in occupational sectors such as construction, transpor- 
tation, shipping, and agriculture are also on the rise, due to the increasing flows of people and goods (Otto and Dalbert 2010). Furthermore, labour policies at national and supranational levels (as in the case of the EU) have facilitated the free flow of workers across jurisdictional boundaries (Dobson and Sennikova 2007). In the Global South, for example, E-RGM is encouraged as a means to sustain local communities and support development via remittances (Varma 2009). Finally, commuting subsidies, communication and transportation infrastructure improvements, and greater flexibility in work arrangements have facilitated the ability of individuals to live farther from their place of work (Green 2004; Green et al. 1999).

In Canada, Alberta's robust oil and gas economy has, in the past decade, attracted tens of thousands of Canadian and foreign workers (De Guerre 2009; Hiller 2009). Across the country, mobility has been encouraged by labour shortages (linked, in part, to Canada's aging population) in other sectors, such as agriculture and horticulture (CAHRC 2009), construction (CSC 2010), and health services, particularly in rural areas (McMullin et al. 2004), and by the expansion of resource extraction and construction in the sparsely populated North. Economic decline in other regions (as in the fisheries in Atlantic Canada, and in association with the more recent recession-induced crises in Canada's forestry and manufacturing sectors) has also pushed workers into jobs requiring extended mobility (see Ommer and Team 2007; MacDonald et al. 2012). Business strategies to reduce costs and increase flexibility, and the shift from single-industry towns to rural turnkey operations and work camps in some sectors, all favour E-RGM over permanent relocation (Markey et al. 2009; Markey and Heisler 2010). In some regions of the country, the shortage of affordable housing, coupled with relatively stagnant real wages, is encouraging some young families to look for cheaper housing outside large urban centres, and others to commute rather than relocate (Statistics Canada 2008; Turcotte and Vezina 2010). Government policies have played a role here. For example, in response to changes in the Canadian Agreement on Internal Trade, provincial and territorial governments have introduced labour mobility legislation intended to boost E-RGM among professionals, semi-professionals, and tradespeople (Agreement on Internal Trade. Office of the Prime Minister). The 2007 Federal Budget Plan presented the Temporary Foreign Worker Program as a means to secure labour in the absence of qualified Canadians (Fudge and MacPhail 2009).

\section{Work journeys in Canada: What do we know?}

Most geographical mobility literature considers some forms of mobility to the exclusion of others (Green 2004; Bell and Ward 1998, 2000). With the exception of the rather small literature on temporary foreign workers and on those employed in work camps and offshore oil rigs (Thomas 2009; Storey 2010; Storey and Shrimpton 1989), Canadian mobility research has focused primarily on migration (i.e., permanent relocation). Our approach to E-RGM in this country is largely informed by the short and long-distance commuting literature. Commuting research has shown that younger people tend to be more mobile (Dion and Coloumbe 2008; Finnie 1998, 1999); commuters tend to be between the ages of 25 and 44 (Turcotte and Vezina 2010); and women are more likely to work close to home (Green and Meyer 1997b; 1992; Shearmur 2006; Turcotte 2005) —a trend that is well known in the larger commuting literature (Ederveen et al. 2007; Hanson 2010; Hanson and Pratt 1988, 1992; Sandow and Westin 2010; Turner and Niemeier 1997). Not surprisingly, commuting also tends to differ according to the industry under consideration (Green and Meyer 1997b; Cubukgil and Miller 1982; Moos and Skaburskis 2010). When sector is combined with a consideration of gender and employment, we can arrive at a clearer picture of how these factors interrelate (Kim et al. 2012). In a study of commuting patterns in rural Northern Ireland, for example, Moss et al. (2004) found that 
Haan et al.: Geography, gender, and occupational sector in employment-related geographical mobility

men commuted longer distances than women, predominantly for employment in the construction and transportation industries. Women's employment, on the other hand, tended to be within public sector positions in local labour markets. The effects of occupational segregation and its relationship to space are well documented in the literature (see Hanson and Pratt 1995).

In addition to their gendered and occupational specificity, commuting patterns differ depending on the geographical region under consideration (Green and Meyer 1997a; Turcotte 2006). Turcotte's research shows considerable variation in average commute times from one region to the next. For example, while commute times in British Columbia remained relatively stable from 1992 to 2005, these times increased in the Prairies and in Atlantic Canada. Many workers who live on the borders of other provinces, such as those in the Ottawa-Gatineau region, travel short distances across a provincial boundary on a daily basis to get to work (Statistics Canada 2008). Others, such as workers from Newfoundland and Labrador and elsewhere, travel longer distances within and between provinces, often for extended periods of time, to work in remote mining, forestry, tourism, and oil and gas installations and in the service sector (MacDonald et al. 2012; Statistics Canada 2008; Storey and Shrimpton 1989; Storey 2010).

\section{Using the Census to understand E-RGM}

Based on the migration and commuting research cited above, we expect our analysis of the 2006 Canadian confidential master file to show that the spectrum of E-RGM in Canada will be influenced by gender, geography, age, and industrial sector. Stated as hypotheses:

1. Younger people will be more mobile than older people;

2. Men will travel greater distances than women;

3. Provinces will have different patterns of E-RGM (reflecting the interplay between distance and local labour market opportunities); and

4. Certain industries will have higher rates of E-RGM than others.

These hypotheses flow from the literature, but existing research provides less guidance on how household contexts, including the number of children living in the household and marital status, influence E-RGM. For example, although commuting across long distances can be challenging for couples (Rotter et al. 1998) and may negatively affect children, particularly in terms of their academic achievement (Vincent and Neis 2011), this does not mean that households with young dependents will not engage in long-distance E-RGM or that negative impacts are inevitable. Kaczmarek and Sibbel's (2008) research with Australian children, for instance, showed that the well-being of those with fathers engaged in fly in/fly out mining operations was not significantly different from those with fathers with local employment.

\section{Data and method}

All analysis in this paper relies on the 2006 Census Master File, available in the Fredericton Research Data Centre. No currently existing large-scale survey or adminstrative data are perfectly suited for studying E-RGM in Canada. While potentially promising, the Labour Force Survey, the Survey of Labour and Income Dynamics, and the Longitudinal Administrative Databank do not contain ad-equate work location information. The census includes both place of work and place of residence data, therefore making it the best available data source for studying E-RGM (Haan and Odynak 2009). However, even the confidential census master files used here have several limitations, as do 
Table 1. Variable descriptions.

\begin{tabular}{|c|c|c|}
\hline Demographic Characteristics & Variable Type & Coding Detail \\
\hline Age & Continuous & \\
\hline Female & Dichotomous $1=$ Yes & $1=$ Yes \\
\hline Married/ Common Law & Dichotomous $1=$ Yes & $1=$ Yes \\
\hline Number of Children & Continuous & \\
\hline Homeowner & Dichotomous $1=$ Yes & $1=$ Yes \\
\hline \multicolumn{3}{|l|}{ Human Capital and Income Characteristics } \\
\hline Less than Highschool & Reference Category & \\
\hline Highschool Diploma & Dichotomous $1=$ Yes & $1=$ Yes \\
\hline College/Trades & Dichotomous $1=$ Yes & $1=$ Yes \\
\hline University Degree & Dichotomous $1=$ Yes & $1=$ Yes \\
\hline \multirow[t]{6}{*}{ Income Groupings } & Discrete & $0=<\$ 25,000$ \\
\hline & & $1=\$ 25,000-\$ 49,999$ \\
\hline & & $2=\$ 50,000-\$ 74,999$ \\
\hline & & $3=\$ 50,000-\$ 74,999$ \\
\hline & & $4=\$ 75,000-\$ 99,999$ \\
\hline & & $5=\$ 100,000+$ \\
\hline \multicolumn{3}{|l|}{ Province of Residence } \\
\hline Nfld/Labrador & Dichotomous $1=$ Yes & $1=$ Yes \\
\hline PEI & Dichotomous $1=$ Yes & $1=$ Yes \\
\hline Nova Scotia & Dichotomous $1=$ Yes & $1=$ Yes \\
\hline New Brunswick & Dichotomous $1=$ Yes & $1=$ Yes \\
\hline Quebec & Dichotomous $1=$ Yes & $1=$ Yes \\
\hline Ontario & Reference Category & \\
\hline Manitoba & Dichotomous $1=$ Yes & $1=$ Yes \\
\hline Saskatchewan & Dichotomous $1=$ Yes & $1=$ Yes \\
\hline Alberta & Dichotomous $1=$ Yes & $1=$ Yes \\
\hline $\mathrm{BC}$ & Dichotomous $1=$ Yes & $1=$ Yes \\
\hline Yukon/NWT/Nunavut. & & $1=$ Yes \\
\hline \multicolumn{3}{|l|}{ Industry of Employment } \\
\hline Agric., Forestry, Fishing and Hunting & Reference Category & \\
\hline Mining, Oil, and Gas Extraction & Dichotomous $1=$ Yes & $1=$ Yes \\
\hline Utilities & Dichotomous $1=$ Yes & $1=$ Yes \\
\hline Construction & Dichotomous $1=$ Yes & $1=$ Yes \\
\hline Manufacturing & Dichotomous $1=$ Yes & $1=$ Yes \\
\hline Wholesale Trade & Dichotomous $1=$ Yes & $1=$ Yes \\
\hline Retail Trade & Dichotomous $1=$ Yes & $1=$ Yes \\
\hline Transportation and Warehousing & Dichotomous $1=$ Yes & $1=$ Yes \\
\hline Information and Cultural Industries & Dichotomous $1=$ Yes & $1=$ Yes \\
\hline Finance and Insurance & Dichotomous $1=$ Yes & $1=$ Yes \\
\hline Real Estate and Rental and Leasing & Dichotomous $1=$ Yes & $1=$ Yes \\
\hline Professional, Scientific and Technical Services & Dichotomous $1=$ Yes & $1=$ Yes \\
\hline Management of Companies and Enterprise & Dichotomous $1=$ Yes & $1=$ Yes \\
\hline Waste Management and Remediation & Dichotomous $1=$ Yes & $1=$ Yes \\
\hline Educational Services & Dichotomous $1=$ Yes & $1=$ Yes \\
\hline Health Care and Social Assistance & Dichotomous $1=$ Yes & $1=$ Yes \\
\hline Arts, Ent. And Recreation & Dichotomous $1=$ Yes & $1=$ Yes \\
\hline Food and Accommodation & Dichotomous $1=$ Yes & $1=$ Yes \\
\hline Other Services & Dichotomous $1=$ Yes & $1=$ Yes \\
\hline Public Administration & Dichotomous $1=$ Yes & $1=$ Yes \\
\hline
\end{tabular}


Haan et al:: Geography, gender, and occupational sector in employment-related geographical mobility

their public-use counterparts. For example, although the 2006 file contains information on place of work, it typically refers to labour force activity in the week prior to the census (which is conducted in May), when some industries (such as tourism) are unlikely to be running at full capacity. Consequently, if a person was not yet working at their regular job on May 16, 2006, their mobility would be concealed. The census is also not capable of determining labour market conditions in specific localities (i.e., employment opportunities), therefore knowledgeability about potential mismatches between jobs and skills is difficult to ascertain. However, we acknowledge that unemployment levels can be used as a proxy.

The master file represents twenty percent of the Canadian population enumerated in the census. Our sample, which contains over 2.2 million observations, consists of all men and women aged 25-54 who were employed full- or part-time in the week prior to the 2006 enumeration. Since 1996, census respondents who completed the long-form questionnaire have been asked to provide both their place of residence and their place of work (if relevant). For those who report both locations, Statistics Canada calculates the straight-line distance between the two points, providing an approximation of the distance an individual travels to work. Although values for this variable are listed in kilometres (to one decimal point), Statistics Canada recodes the value for anyone travelling more than 200 kilometres (one way) to be 200. As such, the variable does not contain accurate information for individuals who travel longer distances to work. Neither do we include in the analysis the 10 percent of Canadians who reported having had no fixed workplace, because there is no information on the distances they travel to get to work, nor have we disaggregated the nearly 8 percent of people working at home.

In the analysis below, we collapse all values under 200 kilometres into similar ordinal categories (0-50 km, 50.1-100 km, 100.1-150 km, 150.1-200 km, 200+ km), creating a dependent variable with five distinct values. We then use the newly created variable above to compare the socio-demographic, occupational, and household characteristics of workers across the E-RGM spectrum, followed by an ordered logit regression with a host of relevant factors. These variables include: age, sex/gender, marital status, number of children in the household, educational level, homeownership (tenure), industry, and income in discrete groupings $(<\$ 25,000 ; \$ 25,000-49,999 ; \$ 50,000-75,000 ; \$ 75,000$ 99,999; $\$ 100,000+){ }^{2}$ Further information on all variables used in the descriptive and multivariate analyses appears in Table 1.

\section{Results}

Table 2 displays the E-RGM categories according to five variables that capture basic demographic (age, sex) and household context (marital status, household tenure, and number of children in the household) characteristics.

Table 2. Demographic characteristics by distance traveled to work (one way), 2006.

\begin{tabular}{lcrrrr}
\hline & $0-50 \mathrm{~km}$ & $50.1-100 \mathrm{~km}$ & $100.1-150 \mathrm{~km}$ & $150.1-200 \mathrm{~km}$ & $200+\mathrm{km}$ \\
\hline Mean age (years) & 40.6 & 40.7 & 39.4 & 37.9 & 36.5 \\
\% Female & 51.8 & 37.7 & 36.5 & 37.4 & 35.3 \\
\% Married/Common-law & 60.9 & 61.8 & 52.5 & 49.0 & 45.5 \\
Number of children & 1.4 & 1.3 & 1.3 & 1.4 & 1.4 \\
\% Homeowner & 81.8 & 88.9 & 86.6 & 83.0 & 82.8 \\
\hline
\end{tabular}

Source: Statistics Canada, Canadian of Population, 2006 Master File.

2. The selection of variables is similar to that used by Sandow and Westin (2010) in their study of long-distance commuting in Sweden. 
Canadian Studies in Population 41, no. 3-4 (2014): Prentice Institute Special Issue

Table 3. Human capital (\%) and income characteristics by distance traveled to work (one way), 2006.

\begin{tabular}{lccccc}
\hline & $0-50 \mathrm{~km}$ & $50.1-100 \mathrm{~km}$ & $100.1-150 \mathrm{~km}$ & $150.1-200 \mathrm{~km}$ & $200+\mathrm{km}$ \\
\hline Less than High School & 11.3 & 11.0 & 12.3 & 13.3 & 12.1 \\
High School Diploma & 26.7 & 25.1 & 26.8 & 28.5 & 28.6 \\
College/Trades & 33.2 & 38.6 & 35.7 & 32.6 & 33.2 \\
University Degree & 28.8 & 25.4 & 25.1 & 25.6 & 26.1 \\
Median Income & $\$ 34,320$ & $\$ 44,228$ & $\$ 37,176$ & $\$ 32,486$ & $\$ 29,624$ \\
\hline
\end{tabular}

Source: Statistics Canada, Canadian of Population, 2006 Master File.

Although there are different ways to present these results, we report here on the distribution of individuals within each E-RGM category. Within each of the E-RGM categories, workers average between 36.5 and 40.7 years of age. In relative terms, older workers are on average more likely to work closer to home than workers in other age groups. Long-distance travelers are roughly four years younger on average than those with short commutes. Consistent with findings in the commuting literature, female representation declines as commuting distance increases, as does the propensity of any individual to be married. It is noteworthy to see, however, that nearly half of all long-distance commuters are either married or living common-law. Interestingly, there are no noteworthy patterns in either the number of children or homeownership status across the spectrum.

Although the odds ratios are statistically significant in Table 3, they are small and do not lend themselves to any clear interpretation that education appears to facilitate mobility. Slightly more than ten percent of all distance commuters report holding less than a high school diploma, compared to slightly more than a quarter of high school diploma holders in all categories. There is a slightly higher propensity for college and trades diploma holders to travel $50.1-100 \mathrm{~km}$, although the discrepancy appears only in that category. Just over one-quarter of long- and short-distance commuters have a university degree.

Table 3 also displays median employment income levels across the E-RGM categories. Somewhat surprisingly, those who work neither close to nor far from home report the highest incomes. For short-distance commuters, the average is $\$ 34,320$, a value that increases to just over $\$ 44,000$ for those traveling 50.1-100 km. Longer-distance commuters see a steady decline in their incomes with distance, so that $200+\mathrm{km}$ travellers dip below $\$ 30,000$ annually.

Table 4 presents E-RGM by province/territory, and although there are mostly similarities by region, a few exceptions stand out. In every part of Canada, well over 90 percent of all commuters travel less

Table 4. Province/territory of residence and distance traveled to work (one way, given in \%), 2006.

\begin{tabular}{lccccc}
\hline & $0-50 \mathrm{~km}$ & $50.1-100 \mathrm{~km}$ & $100.1-150 \mathrm{~km}$ & $150.1-200 \mathrm{~km}$ & $200+\mathrm{km}$ \\
\hline Nfld/Labrador & 91.3 & 2.6 & 1.6 & 0.5 & 4.1 \\
PEI & 95.7 & 2.5 & 0.3 & 0.4 & 1.2 \\
Nova Scotia & 94.7 & 3.1 & 0.5 & 0.3 & 1.4 \\
New Brunswick & 95.2 & 2.6 & 0.6 & 0.4 & 1.2 \\
Quebec & 96.7 & 1.9 & 0.4 & 0.2 & 0.8 \\
Ontario & 95.4 & 3.2 & 0.4 & 0.2 & 0.7 \\
Manitoba & 96.1 & 2.1 & 0.4 & 0.2 & 1.2 \\
Saskatchewan & 93.8 & 2.9 & 0.7 & 0.3 & 2.3 \\
Alberta & 95.2 & 2.3 & 0.7 & 0.3 & 1.5 \\
BC & 96.7 & 1.8 & 0.3 & 0.2 & 1.1 \\
Yukon/NWT/Nunavut. & 93.7 & 0.9 & 1.0 & 1.6 & 2.8 \\
Total & 95.7 & 2.5 & 0.5 & 0.3 & 1.0 \\
\hline
\end{tabular}

Source: Statistics Canada, Canadian of Population, 2006 Master File. 
Haan et al.: Geography, gender, and occupational sector in employment-related geographical mobility

Table 5. Industry of employment and distance traveled to work (one way, given in \%), 2006.

\begin{tabular}{lrcccc}
\hline & $0-50 \mathrm{~km}$ & $50.1-100 \mathrm{~km}$ & $100.1-150 \mathrm{~km}$ & $150.1-200 \mathrm{~km}$ & $200+\mathrm{km}$ \\
\hline Agric., Forestry, Fishing and Hunting & 95.2 & 2.3 & 0.7 & 0.4 & 1.4 \\
Mining, Oil, and Gas Extraction & 83.0 & 5.2 & 2.6 & 1.0 & 8.2 \\
Utilities & 9.0 & 6.0 & 1.0 & 0.8 & 2.2 \\
Construction & 92.2 & 4.0 & 0.9 & 0.5 & 2.4 \\
Manufacturing & 95.4 & 3.4 & 0.4 & 0.2 & 0.6 \\
Wholesale Trade & 95.8 & 3.0 & 0.4 & 0.2 & 0.6 \\
Retail Trade & 97.3 & 1.5 & 0.3 & 0.2 & 0.7 \\
Transportation and Warehousing & 93.1 & 4.1 & 0.8 & 0.4 & 1.6 \\
Information and Cultural Industries & 96.3 & 2.5 & 0.3 & 0.2 & 0.6 \\
Finance and Insurance & 97.2 & 2.1 & 0.3 & 0.2 & 0.4 \\
Real Estate and Rental and Leasing & 97.3 & 1.7 & 0.3 & 0.2 & 0.5 \\
Professional, Scientific and Tech. Services & 96.6 & 2.1 & 0.3 & 0.2 & 0.8 \\
Management of Companies and Enterprise & 96.1 & 2.9 & 0.4 & 0.1 & 0.5 \\
Waste Management and Remediation & 96.2 & 2.3 & 0.4 & 0.2 & 0.9 \\
Educational Services & 95.7 & 2.4 & 0.5 & 0.3 & 1.0 \\
Health Care and Social Assistance & 97.1 & 2.0 & 0.3 & 0.1 & 0.5 \\
Arts, Ent. and Recreation & 95.2 & 2.6 & 0.6 & 0.3 & 1.3 \\
Food and Accommodation & 95.9 & 1.6 & 0.5 & 0.4 & 1.6 \\
Other Services & 96.9 & 1.8 & 0.4 & 0.2 & 0.7 \\
Public Administration & 94.4 & 3.4 & 0.6 & 0.4 & 1.3 \\
\hline
\end{tabular}

Source: Statistics Canada, Canadian of Population, 2006 Master File.

than $50 \mathrm{~km}$ one way to work each day. The province of Newfoundland and Labrador has more than twice as many long-distance commuters as all other provinces (excluding the three Northern territories).

The final descriptive table presents the sample broken down into major industrial groupings, based on the 2002 NAICS classification. The table shows that, once again, the majority of workers find themselves facing relatively short commutes (at least in terms of distance in a straight line), with higher proportions of workers in Mining, Oil and Gas, Utilities, Construction, and Transportation and Warehousing travelling longer distances. This is particularly true for those in Mining and Oil and Gas, where nearly one in five traveled more than 50 kilometres to get to work in 2006.

Although in most cases individuals travel relatively short distances to work, there is a significant contingent of longer-distance travelers, particularly in some regions and sectors. It is important to learn more about this proportion of the population, since certain industries like mining and oil and gas appear to depend heavily upon the availability of a labour force that is willing and able to engage in long commutes.

\section{Multivariate Results}

In this portion of the paper, the descriptive results are further contextualized by simultaneously modeling the effect of all characteristics on the outcome of interest. Since our dependent variable-distance to work-is ordinal, regular linear probability models are inappropriate. In addition to the many other well-known requirements for linear regression (homoscedasticity of error variance, normally distributed errors, etc.), it assumes equal distances between response categories of the dependent variable. Although at times this may be plausible, there are many instances where it 
Table 6: Logistic regression analysis of distance traveled to work (one way), 2006.

\begin{tabular}{|c|c|c|c|}
\hline Demographic Characteristics & Odds Ratio & Std Error & Sig. \\
\hline Age & 0.989 & 0.000 & $* * *$ \\
\hline Female & 0.627 & 0.005 & $* * *$ \\
\hline Married/ Common Law & 0.750 & 0.006 & $* * *$ \\
\hline Number of Children & 0.950 & 0.003 & $* * *$ \\
\hline Homeowner & 1.475 & 0.015 & $* * *$ \\
\hline \multicolumn{4}{|l|}{ Human Capital and Income Characteristics } \\
\hline Less than Highschool & 1.000 & & \\
\hline Highschool Diploma & 0.963 & 0.011 & $* * *$ \\
\hline College/Trades & 1.078 & 0.013 & $* * *$ \\
\hline University Degree & 0.884 & 0.011 & $* * *$ \\
\hline Income Groupings & 1.084 & 0.004 & $* * *$ \\
\hline \multicolumn{4}{|l|}{ Province of Residence } \\
\hline Nffld/Labrador & 1.963 & 0.042 & $* * *$ \\
\hline PEI & 0.949 & 0.048 & \\
\hline Nova Scotia & 1.167 & 0.022 & $* * *$ \\
\hline New Brunswick & 1.008 & 0.022 & \\
\hline Quebec & 0.685 & 0.006 & $* * *$ \\
\hline Ontario & 1.000 & & \\
\hline Manitoba & 0.847 & 0.016 & $* * *$ \\
\hline Saskatchewan & 1.335 & 0.023 & $* * *$ \\
\hline Alberta & 0.881 & 0.010 & $* * *$ \\
\hline $\mathrm{BC}$ & 0.729 & 0.009 & $* * *$ \\
\hline Yuk/NWT/Nun. & 1.267 & 0.065 & $* * *$ \\
\hline \multicolumn{4}{|l|}{ Industry of Employment } \\
\hline Agric., Forestry, Fishing and Hunting & 1.000 & & \\
\hline Mining, Oil, and Gas Extraction & 3.594 & 0.094 & $* * *$ \\
\hline Utilities & 1.925 & 0.060 & $* * *$ \\
\hline Construction & 1.476 & 0.035 & $* * *$ \\
\hline Manufacturing & 0.888 & 0.019 & $* * *$ \\
\hline Wholesale Trade & 0.832 & 0.021 & $* * *$ \\
\hline Retail Trade & 0.572 & 0.013 & $* * *$ \\
\hline Transportation and Warehousing & 1.398 & 0.033 & $* * *$ \\
\hline Information and Cultural Industries & 0.745 & 0.023 & $* * *$ \\
\hline Finance and Insurance & 0.620 & 0.017 & $* * *$ \\
\hline Real Estate and Rental and Leasing & 0.572 & 0.021 & $* * *$ \\
\hline Professional, Scientific and Technical Services & 0.736 & 0.018 & $* * *$ \\
\hline Management of Companies and Enterprise & 0.843 & 0.083 & \\
\hline Waste Management and Remediation & 0.800 & 0.022 & $* * *$ \\
\hline Educational Services & 1.055 & 0.025 & * \\
\hline Health Care and Social Assistance & 0.733 & 0.017 & $* * *$ \\
\hline Arts, Ent. And Recreation & 1.005 & 0.031 & \\
\hline Food and Accommodation & 0.917 & 0.022 & $* * *$ \\
\hline Other Services & 0.664 & 0.018 & $* * *$ \\
\hline Public Administration & 1.143 & 0.027 & $* * *$ \\
\hline
\end{tabular}

$\begin{array}{llllllllllll}* / \text { cut1 } & 2.529 & 0.272 & \text { /cut2 } & 3.475 & 0.275 & \text { /cut3 } & 3.800 & 0.028 & \text { /cut4 } & 4.026 & 0.028\end{array}$

* "/cut1" refers to the estimated cut-point on the latent variable, where those traveling $50.1-100 \mathrm{~km}$ begin to differ from those with the shortest commutes. Respondents with a value of 2.529 or less on the underlying latent variable that produced our observed dependent variables would be classified as low commuters when all other independent variables are held at their lowest values. The small gaps between the remaining cutpoints reveal the extreme diversity in the remaining three categories of the dependent variable (100.1-150, 150.1-200, and 200+ km commuters). 
is questionable. If, for example, an individual is asked to rank her or his happiness on a Likert scale (very unhappy, unhappy, happy, very happy), an individual may be more or less likely to report extreme happiness than happiness, happiness than indifference, etc. As such, the conceptual distance between response categories differs.

It is possible to model the outcomes as though there was no relationship whatsoever between response categories (as with multinomial logit or probit models), but this ignores the inherent ordering of the dependent variable. As the most appropriate analytical strategy, we chose ordered logit regression techniques, an extension of the more commonly used binary logit model that allows more than two response categories in the dependent variable.

As this pertains to our study, the implication is that the cut-points that were arbitrarily drawn by us between categories of the dependent variable do not have a tremendous impact on the results. In other words, our decision to divide the dependent variable into $50-\mathrm{km}$ categories is of little significance, since ordinal logit models derive their own cut-points between response categories. Each cut-point tells us about the cumulative distribution of answers for individuals with the lowest value of all independent variables (the reference group). The ordered logit model allows for differences in intercepts while assuming equality of slopes. Except for the addition of these cut-points, however, interpretation of coefficients is very similar to that of an ordinary logit model, except that rather than calculating the coefficient estimates for transition of the dependent variable from 0 to 1 , the values now reflect a transition from the lowest category to all other categories combined.

Consistent with the findings from previous research on commuting and the descriptive results shown earlier, the regression results in Table 6 show that younger people tend to have higher overall levels of mobility (hypothesis 1). Men and women both engage in all-distance commutes, but males are nearly $40 \%$ more likely than females to engage in more extensive forms of employment-related geographical mobility, as predicted by hypothesis 2 . Having children has a slightly negative effect on commuting distance, whereas the propensity for homeowners to commute longer distances increases by nearly 50 percent. Consistent with the descriptive results is the relatively small impact of education. Although the differences between attainment categories is statistically significant, the differences are small, and only college/trades graduates have a slightly higher propensity to commute than the reference group (less than high school). Unlike the descriptive results shown earlier, the addition of controls led to a slightly higher propensity for higher-income earners to travel further distances. Once again, however, the effect is small.

Provincial/territorial effects vary widely. In Newfoundland and Labrador, the propensity to commute is nearly twice as high as it is for Ontario residents. This propensity is significantly lower for Albertans. All other provinces/territories sit within the two extremes, lending further weight to the notion of regional variation in commuting behaviour, as postulated in hypothesis 3 .

Finally, some of the highest variations can be seen across industrial sectors. Compared to Agriculture, Forestry, Fishing and Hunting, workers in the Mining and Oil and Gas industries are more than three times as likely to commute longer distances. Those working in Utilities are nearly twice as likely, and Construction Workers and Transport and Warehouse Operators are roughly 1.5 times as likely, to travel to work. Except Education and Public Administration (where the positive effects are fairly slight), all other industries contain workers who either do not differ from the reference group (Management and Arts categories) or are less likely to commute. The standouts here are those in Real Estate or Retail Trade, where workers in either industry are nearly half as likely to commute.

Turning now to the cut-points, given that ordinal logit models assume a latent variable that underlies the observed indicator, "_cut1" refers to the estimated cut-point on the latent variable, 
where those traveling 50.1-100 km begin to differ from those with the shortest commutes. Respondents with a value of 2.529 or less on the underlying latent variable that produced our observed dependent variables would be classified as low commuters, when all other independent variables are held at their lowest values. In other words, on the underlying latent variable, 1-50 km and 50.1-100 $\mathrm{km}$ commuters are sufficiently similar to be treated as a single category. The small gaps between the remaining cut-points reveal the extreme diversity in the remaining three categories of the dependent variable (100.1-150, 150.1-200, and 200+ km commuters). These are the people for whom a broader conceptualization of E-RGM is needed.

There are several ways to read these results for the longer commute portion of the sample, none of which can be verified by our analysis. First, longer-distance commuters may be composed of a substantial number of professionals with high incomes (even though the median income for this group is lower). These people may have therefore chosen to be mobile rather than been forced to be mobile. We use the term forced, realizing that under few circumstances are individuals unable to exert any agency regarding their geographical mobility. Exceptions could include refugees and asylum seekers (see Castles 2003 for a discussion of forced migration). Forced mobility, in this instance, refers more to what Coe and Jordhus-Lier (2010: 219) call constrained agency (i.e., when "lack of structural power goes hand in hand with political suppression" and therefore shapes individual mobility). Having said this, professional or dual-career couples, such as academics, sometimes have to work long distances apart, perhaps even in separate countries, states, or provinces-both because of the nature of their work and work availability (Gross 1980; Holmes 2004). In this context, mobility is driven in part by the requirements and options available in the sectors.

Another contingent of longer-distance commuters likely includes those with limited options in the local labour market. What is important to understand about this group is the fact that this workforce is largely comprised of men (men outnumber women nearly 3:1). Why men outnumber women by such a margin is unclear. It may be because they comprise a surplus workforce that is available and willing to engage in mobile work because they have few other options. This may be due to either a small individual skill-set or a lack of demand for the skills they do possess closer to home. This is consistent with the higher propensity to commute for those living in Atlantic Canada. Alternatively, their household requirements may be minimal relative to those of women, enabling them to look for work farther afield.

To fully understand the nuances of the categories of workers who commute longer distances, a fuller analysis of the extent of constraint and choice experienced by workers engaged in E-RGM must be considered. Wider labour market shifts, household dynamics, and policy change are all potentially fruitful areas of inquiry in this respect. By examining the spectrum of E-RGM and highlighting the similarities and differences among workers found along it, we can now begin to ask who is and is not rendered precarious through E-RGM, and why and with what consequences, particularly for families and communities.

\section{Conclusion}

We began this paper with the acknowledgement that changing national and international labour markets, better transportation and communications infrastructure, and shifting policy regimes are shaping individual work-related geographical mobility in new and important ways. In some cases, mobility is a choice. In others, it comes as a result of constraints. The urgent need for systematic comparative research across the full E-RGM spectrum - from those who work at home (such as telecommuters) or live very close to their workplace through to those who engage in regular and often 
Haan et al.: Geography, gender, and occupational sector in employment-related geographical mobility

prolonged journeys to work- has never been greater. In this paper, we have used the 2006 Canadian Census to explore the potential in these data for this kind of approach, organizing the data according to the distance from an individual's place of work to their place of residence. We examined workers engaged in five categories of E-RGM according to their socio-demographic and household characteristics in the 2006 census. Our purpose was to understand whether and how individuals, households, and sectors in each of these categories differed, in order to set the stage for future comparative research. The characteristics of workers, household composition, and sectors differ in terms of their engagement with E-RGM across the spectrum, from short-distance to long-distance commutes.

Despite the constraints of these data (i.e., they do not tell us anything about the frequency of commutes, their complexity, or the time involved), it seems that long-distance commuters are characteristically distinct from shorter-distance commuters. In answer to our research questions and in support of each of our hypotheses, it is young men residing in Newfoundland and Labrador and working in oil, mining, and gas who are most likely to engage in employment-related geographic mobility.

In closing, the census is a useful place from which to begin an analysis of the E-RGM spectrum. However, in order to gain a deeper understanding and to assess its impacts on workers, employers, households, communities, and society at large, we do require more comparative, multi-method, and longitudinal research. What is it about residing in the province of Newfoundland and Labrador that makes commuting long distances much more likely, and why does this appeal most to men in that province? Furthermore, we do need further inquiry into whether, and to what extent, these longdistance commutes reflect choice or constraint among commuters. What are, in fact, the crossroads that they face? It is to these questions that we turn our future work and analyses.

\section{References}

Agreement on Internal Trade. Office of the Prime Minister. http://pm.gc.ca/eng/media.asp?id=2385 (Retrieved October 20th, 2011).

Ali, K., M.R. Olfert, and M. Partridge. 2011. Urban footprints in rural Canada: Employment spillovers by city size. Regional Studies 45(2):239-260.

Anderson, E.A. 1992. Decision-making style: Impact on satisfaction of the commuter lifestyle. Journal of Family and Economic Issues 13(1):5-21.

Baldacchino, G., R. Greenwood, and L. Felt (eds.). 2009. Remote Control: Governance Lessons For and From Small, Insular and Remote Regions. St John's NL: ISER Press.

Bauman, Z. 2000. Liquid Modernity. Cambridge: Polity Press.

Bell, M., and G. Ward. 2000. Comparing temporary mobility with permanent migration. Tourism Geographies 2(1):97-107.

CAHRC (Canadian Agricultural Human Resource Council). 2009. Labour Market Information on Recruitment and Retention in Primary Agriculture. Ottawa: Canadian Agricultural Human Resource Council.

Castles, S. 2003. Towards a sociology of forced migration and social transformation. Sociology 37:13-34.

Clark, W. 2000. Traffic report: weekday commuting patterns. Canadian Social Trends 56:18-22.

Coe, N.M., and D.C. Jordhus-Lier. 2011. Constrained agency? Re-evaluating the geographies of labour. Progress in Human Geography 35(2):211-233. 
Cohen, R.L. 2010. Rethinking 'mobile work': Boundaries of space, time and social relation in the working lives of mobile hairstylists. Work, Employment \& Society 24(1):65-84.

CSC (Construction Sector Council). 2005. Working mobile: a study of labour mobility in Canada's industrial construction sector. Ottawa: Construction Sector Council. http://www.csc-ca.org/pdf/ WorkingMobile_Report_E.pdf.

2010. Construction looking forward: An assessment of construction labour markets from 2010 to 2018. National Summary. Ottawa: Construction Sector Council.

Cubukil, A., and E.J. Miller. 1982. Occupational status and the journey-to-work. Transportation 11(30):251-276.

HRLE (Department of Human Resources, Labour and Employment). 2011. Nenfoundland and Labrador Labour Market: Outlook 2020. St. John's, NL: Government of Newfoundland and Labrador.

De Guerre, K. 2009. Temporary foreign workers in Alberta's oil sector. Working Paper. Sussex: Sussex Centre for Migration Research, University of Sussex. Report No. 54.

Dion, P., and S. Coulombe. 2008. Portrait of the mobility of Canadians in 2006: Trajectories and characteristics of migrants. Catalogue No. 91-209. Ottawa: Minister of Industry. http://www. statcan.gc.ca/pub/91-209-x/91-209-x2004000-eng.pdf.

Dobson, J.R., and I. Sennikova. 2007. From fundamental freedom to political and economic 'Hot Potato' in 50 years: Labour mobility and migration within the EU. Journal of Business Economics and Management 8(2):123-136.

Duxbury, L., C. Higgins, C. Lee, and S. Mills. 1992. Balancing work and family: A study of the Canadian work force. Optimum 23:27-28.

Ederveen S., R. Nahuis, and A. Parikh. 2007. Labour mobility and regional disparities: The role of female labour participation. Journal of Population Economics 20(4):895-913.

Finnie, R. 1998. Interprovincial Mobility in Canada: A Longitudinal Analysis. Ottawa: Human Resources Development Canada.

. 1999. Inter-provincial migration in Canada: A longitudinal analysis of movers and stayers and the associated income dynamics. Canadian Journal of Regional Science XXII(3):227-262.

Foulkes, M., and K.B. Newbold. 2008. Poverty catchments: migration, residential mobility, and population turnover in impoverished rural Illinois communities. Rural Sociology 75(3):440-462.

Fudge, J., and F. MacPhail. 2009. The Temporary Foreign Worker Program in Canada: Low-skilled workers as an extreme form of flexible labor. Comparative Labor Law Policy Journal 31(1):5-45.

Green, A. 2004. Is relocation redundant? Observations on the changing nature and impacts of employment-related geographical mobility in the UK. Regional Studies 38(6):629-642.

Green, M.B., and S.P. Meyer. 1997a. An overview of commuting in Canada with special emphasis on rural commuting and employment. Journal of Rural Studies 13(2):163-175.

. 1997b. Occupational stratification of rural commuting, in Rural Employment: An International Perspective, edited by R.D. Bollman and J.M. Bryden. Wallingford (UK): CAB International, in association with the Canadian Rural Revitalization Foundation, pp. 225-238. 
Haan et al:: Geography, gender, and occupational sector in employment-related geographical mobility

Green, A.E., T. Hogarth, and R.E. Shackleton. 1999. Longer distance commuting as a substitute for migration in Britain: A review of trends, issues and implications. International Journal of Population Geography 5(1):49-67.

Gross, H.E. 1980. Dual-career couples who live apart: Two types. Journal of Marriage and the Family 42(3):567-576.

Haan, M., and D. Odynak. 2009. Enumerating Alberta's shadow population. Report submitted to the Office of Statistics and Information of the Government of Alberta. Submitted August 26, 2009.

Hanson, S. 2010. Gender and mobility: New approaches for informing sustainability. Gender, Place \& Culture 17(1):5-23.

Hanson, S., and G. Pratt. 1988. Reconceptualizing the links between home and work in urban geography. Economic Geography 64(4):299-321.

-1995. Gender, Work, and Space. London and New York: Routledge.

1992. Dynamic dependencies: A geographic investigation of local labor markets. Economic Geography 68(4):373-405.

Harris, S., A. Alasia, and R.D. Bollman. 2008. Rural commuting: Its relevance to rural and urban labour markets. Rural and Small Town Canada Analysis Bulletin 7(6):1-23. http://www.statcan.gc.ca/pub/21006-x/21-006-x2007006-eng.pdf

Heisz, A., and S. LaRochelle-Cote. 2005a. Getting to work. Canadian Social Trends Winter:14-17. http:// www.statcan.gc.ca/pub/11-008-x/2005003/article/8967-eng.pdf

- 2005b. Work and commuting in Census Metropolitan Areas, 1996-2001. Business and Labour Market Analysis Division. Ottawa: Statistics Canada. http://www.statcan.gc.ca/pub/89-613-m/89613-m2005007-eng.pdf

Helminen, V., and M. Ristimaki. 2007. Relationships between commuting distance, frequency and telework in Finland. Journal of Transport Geography 15(5):331-342.

Hiller, H.H. 2009. Second Promised Land: Migration to Alberta and the Transformation of Canadian Society. Montreal and Kingston: McGill-Queen's University Press.

Holmes, M. 2004. An equal distance? Individualisation, gender and intimacy in distance relationships. The Sociological Review 52(2):180-200.

Kaczmarek, E.A., and Sibbel, A.M. (2008). The psychosocial well-being of children from Australian military and fly-in/fly-out (FIFO) mining families. Community, Work \& Family 11(3):297-312.

Kim, S.S., Y. Chun, and W. Lee. 2012. Exploring urban commuting imbalance by jobs and gender. Applied Geography 32(2):532-545.

Levine, I. 2004. Living apart together. Current Sociology 52(2):223-240.

Lippel, K. 2010. Workers' compensation for asbestos related disease in five Canadian provinces. Final report of the Occupational Health Clinics for Ontario Workers and the Canadian Partnership against Cancer. http://www.droitcivil.uottawa.ca/index.php?option $=$ com_docman\&task $=$ doc_dow

MacDonald, M., P. Sinclair, and D. Walsh 2012. Labour migration and mobility in Newfoundland: Social transformation and community in three rural areas, in The Social Transformation of Rural Canada: New Insights into Community, Culture and Citizenship, edited by M. Reed and J. Parkins. Vancouver: UBC Press, pp. 120-130. 
Markey, S., G. Halseth, and D. Manson. 2009. Contradictions in hinterland development: Challenging the local development ideal in Northern British Columbia. Community Development Journal 44(2):209_ 229.

Markey, S., and K. Heisler. 2010. Getting a fair share: Regional development in a rapid boom-bust rural setting. CJRS (Online)/ RCSR (En Ligne) 33(3):49-62.

Marshall, J. 2009. Tides of Change on Grand Manan Island. Montreal and Kingston: McGill-Queen's University Press.

McMullin, J.A., M. Cooke, and R. Downie. 2004. Labour Force Ageing and Skill Shortages in Canada and Ontario. Research Report No. W/24. Ottawa: Canadian Policy Research Networks Inc.

Mitchell, C.J.A. 2007. Population change and external commuting in Canada's rural and small town municipalities. Canadian Journal of Regional Science 28(3):461-486.

Moos, M., and A. Skaburskis. 2010. Workplace restructuring and urban form: The changing national settlement patterns of the Canadian workforce. Journal of Urban Affairs 32(1):25-53.

Moss, J.E., C.G. Jack, and M.T. Wallace. 2004. Employment location and associated commuting patterns for individuals in disadvantaged rural areas in Northern Ireland. Regional Studies 38(2):121-136.

Ommer, R.E., and Coasts Under Stress Team. 2007. Coasts Under Stress: Restructuring and Social-Ecological Health. Montreal: McGill-Queen's University Press.

Otto, K., and C. Dalbert. 2010. New challenges for human resource management: Readiness to perform a mobile job and its antecedents. International Journal of Human Resource Management 21:600-614.

Penninx, R., D. Spencer, and N.V. Hear. 2008. Migration and integration in Europe: The state of research. Report Commissioned for New Opportunities for Research Funding Cooperation in Europe (NORFACE). Oxford: Economic and Social Research Council (ESRC) Centre on Migration, Policy and Society (COMPAS), University of Oxford.

Preibisch, K. 2010. Pick-your-own labor: Migrant workers and flexibility in Canadian agriculture. International Migration Review 44(2):404-441.

Ravenstein, E.G. 1885. The laws of migration. Journal of the Statistical Society of London 48(2):167-235.

Rotter, J.C., D.E. Barnett, and M.L. Fawcett. 1998. On the road again: Dual-career commuter relationships. The Family Journal 6(1): 46-49.

Sandow, E., and K. Westin. 2010. The persevering commuter: Duration of long-distance commuting. Transportation Research Part A. 44:433-445.

Sauvé, M. 2007. Canadian dispatches from medical fronts: Fort McMurray. Canadian Medical Association Journal 177(1):26.

Shearmur, R. 2006. Travel from home: An economic geography of commuting distances in Montreal. Urban Geography 27(4):330-359.

Shearmur, R., and B. Motte. 2009. Weak ties that bind: Do commutes bind Montreal's central and suburban economies? Urban Affairs Review 44(4):490-524.

Shearmur, R., and M. Polese. 2007. Do local factors explain local employment growth: Evidence from Canada, 1971-2001. Regional Studies 41(4):453-471. 
Haan et al.: Geography, gender, and occupational sector in employment-related geographical mobility

Stabler, J., and R.C. Rounds. 1997. Commuting and rural employment on the Canadian prairies, in Rural Employment: An International Perspective, edited by R.D. Bollman and J.M. Bryden. Wallingford: CAB International, pp.193-204.

Statistics Canada 2010a. 2006 Census Dictionary. Catalogue no. 92-566-X. http://www12.statcan.gc.ca/ census-recensement/2006/ref/dict/pdf/92-566-eng.pdf

—. 2010b. 2006 Census Dictionary. Catalogue no. 92-566-X. http://www12.statcan.gc.ca/censusrecensement/2006/ref/dict/pdf/92-566-eng.pdf

—. 2008. Commuting Patterns and Places of Work of Canadians, 2006.

Census. Ottawa: Statistics Canada. http://www12.statcan.ca/census-recensement/2006/as-sa/97-561/ pdf/97-561-XIE2006001.pdf

— 2006. Census of Population, 2001 [Canada]: Public Use Sample Tape: Individuals File. [machine readable data file]. Ottawa: Statistics Canada.

Storey, K. (2010). Fly-in/Fly-out: Implications for community sustainability. Sustainability 2:1161-1181.

Storey, K., and M. Shrimpton. 1989. Impacts on Labour of Long-Distance Commuting Employment in the Canadian Mining Industry. St. John's NL: Memorial University of Newfoundland.

Temple Newhook, J., B. Neis, L. Jackson, S.R. Roseman, P. Romanow, and C. Vincent. 2011. Employment-related mobility and the health of workers, families, and communities: The Canadian context. Labour/Le Travail 67:121-155.

Thomas, M. 2009. Labour migration and temporary work: Canada's foreign-worker programs in the "New Economy". in Interrogating the New Economy: Restructuring Work in the $21^{\text {st }}$ Century, edited by N.J. Pupo and M. Thomas, pp. 149-172.

Turcotte, M.L. 2005. Like commuting? Workers' perceptions of their daily commute. Canadian Social Trends 82:35-41. http://www.statcan.gc.ca/pub/11-008-x/2006004/pdf/9516-eng.pdf

Turcotte, M., and M. Vezina. 2010. Migration from central to surrounding municipalities in Toronto, Montreal and Vancouver. Canadian Social Trends 90:3-24. http://www.statcan.gc.ca/pub/11008-x/2010002/article/11159-eng.pdf

Turner, T., and D. Niemeier. 1997. Travel to work and household responsibility: New evidence. Transportation 24(4):397-419.

van der Klis, M., and C.H. Mulder. 2008. Beyond the trailing spouse: The commuter partnership as an alternative to family migration. Journal of Housing and the Built Environment 23:1-19.

Varma, S. 2009. Facilitating temporary labour mobility in African least-developed countries: Addressing mode 4 supply-side constraints. Issue Paper No. 10. Geneva: International Centre for Trade and Sustainable Development.

Vincent, C.D., and B.L. Neis. 2011. Work and family life: Parental work schedules and child academic achievement. Community, Work \& Family (iFirst):20-21. DOI:10.1080/13668803.2010.535664

Vosko, L. 2006. Precarious employment: Towards an improvement understanding of labour market insecurity, in Precarious Employment: Understanding Labour Market Insecurity in Canada, edited by L. Vosco. Montreal: McGill-Queens University Press, pp. 3-39.

- 2010. Managing the Margins: Gender, Citizenship and the International Regulation of Precarious Employment. Oxford: Oxford University Press. 